soluble fish proteins obtained by enzymatic treatment of fresh fish offals dried according to the Hatmaker or Spray methods. Six artificial milks were made by dry pelleting of either cow skimmilk powder (control diet) or of two concentrates of soluble fish proteins ( 83 or 87 p. Ioo proteins) prepared by means of two different technological methods, providing 33, 66 or I00 p. Ioo of the total proteins. The diets were isoprotidic (25 p. roo crude protein) and isolipidic ( 25 p. roo fat). Complementary lipids were provided with tallow "Ist juice", and a variable proportion of maltodextrine was introduced into the feeds containing fish concentrates. The milk substitutes were offered between 12 and 35 days of age and progressively replaced by a standard starter ration containing $20 \mathrm{p}$. Ioo proteins. Performances of the animals varied both with the level and with the kind of soluble concentrates used (CPSP 80 and CPSP9o). Weight gain generally decreased when the substitution rate of milk proteins by fish proteins increased. However, when a third of the proteins was supplied by one of the soluble concentrates (CPSP 80) the performances of the animals were identical to those of the controls and comparable to those of the unweaned piglets. These results may be explained by the excellent health of the animals (decrease in frequency of diarrhoea).

\title{
UTILISATION DIGESTIVE DE L'ÉNERGIE ET DES MATIẼRES AZOTÉES DE LA FÉVEROLE, SOUS FORME ENTIËE OU DÉCORTIQUÉE, EN COMPARAISON AVEC LE TOURTEAU DE SOJA
}

\author{
Y. HENRY et D. BOURDON \\ Station de Recherches sur l'Élevage des Porcs, \\ Centre national de Recherches zootechniques, I. N.R. A., \\ 78350 Jouy en Josas
}

\section{RÉSUMÉ}

L'utilisation digestive de l'énergie et des matières azotées de la féverole par le Porc en croissance a été étudiée sous forme entière ou décortiquée, en comparaison avec le tourteau de soja.

Le CUD apparent de l'énergie de la graine entière est égal à 87 p. Ioo. La valeur en énergie digestible, $3900 \mathrm{kcal}$ par $\mathrm{kg}$ de matière sèche, représente $93 \mathrm{p}$. Ioo de celle du tourteau de soja à $44 \mathrm{p}$. roo de matières azotées.

Avec une digestibilité apparente des matières azotées de l'ordre de 80 à 85 p. roo, la féverole se classe sensiblement au même niveau que l'orge ( $80 \mathrm{p}$. Ioo), mais nettement en dessous du tourteau de soja (9o p. Ioo environ).

Le décorticage de la graine de féverole a pour effet d'élever le CUD de l'énergie à 94 p. Ioo et celui des matières azotées à 89 . La féverole décortiquée présente ainsi une valeur d'énergie digestible de 4 I oo $\mathrm{kcal}$ par $\mathrm{kg}$ de matière sèche, soit $5 \mathrm{p}$. Ioo de plus que la féverole entière et 2 p. Ioo de moins que le tourteau de soja 44, tandis que la digestibilité de ses matières azotées est sensiblement la même que celles du tourteau de soja cuit. 


\title{
SUMMARY
}

\begin{abstract}
APPARENT DIGESTIBILITY OF ENERGY AND PRO'TEIN IN HORSEBEAN,
\end{abstract} WITH OR WITHOUT DEHULIING, AS COMPARED TO SOYBEAN OIL MEAL

The apparent digestibility of energy and protein in horsebeans, by the growing pig, has been studied, with or without dehulling, as compared to soybean oil meal, (44 p. Ioo protein).

The digestibility coefficient for energy in the whole seed was $87 \mathrm{p}$. Ioo. Its digestible energy content was $3900 \mathrm{kcal}$ per $\mathrm{kg}$ dry matter, i.e. 93 p. Ioo of the digestible energy of soybean oil meal.

The apparent digestibility of protein was similar to that of barley (between 80 and $85 \mathrm{p}$. Ioo), and much lower than that of soybean oil meal (around 90 p. roo).

After dehulling, the apparent digestibility of energy was raised to $94 \mathrm{p}$. Ioo and that of protein to $89 \mathrm{p}$. Ioo. The corresponding digestible energy content was 4 Ioo kcal per $\mathrm{kg}$ dry matter, that is 5 p. I oo higher than that of the whole seed, and 2 p. Ioo lower than that of soybean oil meal. The apparent digestibility of protein, was almost the same for dehulled raw horsebeans and cooked soybean oil meal.

\section{VALEUR ÉNERGÉTIQUE DU POIS FOURRAGER ET UTILISATION PAR LE PORG EN FINITION}

\author{
D. BOURDON et Y. HENRY \\ Station de Recherches sur l'Élevage des Porcs, \\ Centre national de Recherches zootechniques, I. N.R.A., \\ 78350 Jouy en Josas

\section{RÉSUMÉ}

Le Pois Fourrager présente pour le porc une valeur énergétique voisine de celle de la Féverole, soit $3870 \mathrm{kcal}$ d'énergie digestible (ou $3700 \mathrm{kcal}$ d'énergie métabolisable) par kg de matière sèche pour un CUD apparent de l'énergie de 87,7. La digestibilité apparente de ses matières azotées est de 1'ordre de 84 p. roo, plus élevée que pour la Féverole. Au-delà de $50 \mathrm{~kg}$ de poids vif, le Pois Fourrager peut remplacer la totalité du tourteau de soja en complément de l'orge, au taux de 30 p. Ioo, sans qu'il en résulte une modification des performances de croissance. Cependant l'efficacité alimentaire globale accuse une diminution de l'ordre de 3 p. Ioo au taux d'incorporation considéré;

\section{SUMMARY}

\section{ENERGY VALUE OF FIELD-PEAS AND ITS U'TILIZATION BY FINISHING PIGS}

The energy value of field-peas given to pigs was similar to that of horse-beans, i.e. 3870 kcal digestible energy (or $3700 \mathrm{kcal}$ metabolisable energy) per kg dry matter, the apparent digestibility coefficient of the energy being 87.7 . The apparent digestibility of crude protein was about 84 p. roo 